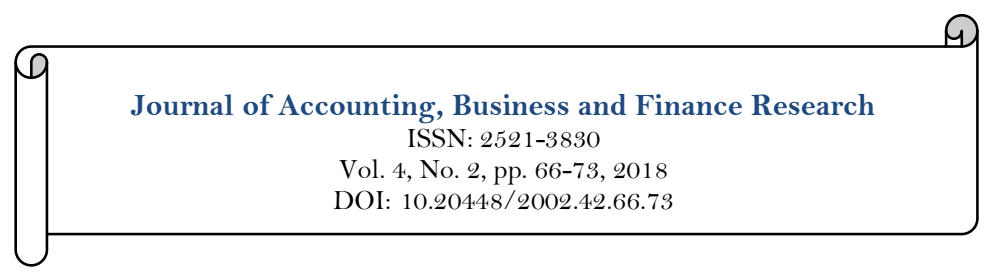

\title{
Comprehensive Credit Risk Management of Policy Export Credit Insurance Institutions
}

\author{
Ming Liu ${ }^{1}$ \\ Jie $\mathbf{Z h u}^{2}$ \\ Yuanchao Bian ${ }^{3 *}$ \\ Liping Chen ${ }^{4}$
}

'Business School, Nanjing Normal University, China.

${ }^{2}$ School of Economics and Management, Nanjing Polytechnic Institute, College of Management, University of Massachusetts Boston, China.

school of Economics and Management, Southeast University, China.

Email:bycdats@163.com

${ }^{4}$ School of Foreign Languages and Cultures, Nanjing Normal University, China.

\begin{abstract}
In the context of the turbulent international political situation, the uneven development of social development and the stagnation of economic development in recent years, China's promotion of foreign trade and economic transformation and upgrading and the "Belt and Road" strategy are necessary to pay more attention to the research and control of export credit risks, so policy exports is particularly urgent and important for credit insurance institutions to conduct research on credit risk control activities in support of the "going out" process of Chinese goods and capital. At the same time, unlike general commercial financial institutions, the starting point and foothold of credit risk management of policy financial institutions should be "maximizing social benefits" rather than the "maximum economic benefits" of traditional risk management theories. The target set of the risk management system of the export credit insurance institution is repositioned. Therefore, this paper attempts to sort out the research results of the existing policy-oriented export credit institutions, and from the perspective of comprehensive risk management, through the analysis of the characteristics and difficulties of the credit risk management of policy-oriented export credit insurance institutions, the company builds a comprehensive credit risk management system. The ideas and structure are discussed, and preliminary suggestions are put forward on the basis of this, in order to provide reference for the company to further improve the comprehensive risk management system.
\end{abstract}

Keywords:

Comprehensive credit risk management

Policy export credit insurance institutions

The "Belt and Road" strategy

The "going out"

The perspective of comprehensive

risk management

Thoughts on comprehensive credit risk management.

Licensed:

This work is licensed under a Creative Commons Attribution 4.0 License.

Publisher:

Scientific Publishing Institute

Funding: This paper is sponsored by The Project of Philosophy and Social Science Research in Colleges and Universities of Jiangsu Province : An Empirical Study on the Impact of Inclusive Finance on Regional Economic Development in Jiangsu Province (Grant No.2017SJBo622). Competing Interests: The authors declare that they have no competing interests.

Acknowledgement: Special thanks for Jiangsu Overseas Visiting Scholar Program for University Prominent Toung \& Middle-aged Teachers and Presidents (2017) for financial support and thanks for University of Massachusetts Boston College of Management for academic advising.

\section{The Presentation and Basic Content of the Comprehensive Risk Management Concept}

Under the traditional concept, the term "risk" implies the uncertainty of costs and benefits and the possibility of losses. This concept contains two aspects of the implication: first, risk is the source of losses for natural persons or social subjects; second, through effective control of risks, especially the control of risk and 
return balance, can reduce losses and even obtain Corresponding income. Therefore, the effective management of risks will inevitably become a necessary condition for all organizations to maintain long-term sustainable development.

The concept of risk awareness and risk management has been germinated for thousands of years, but it has become a separate discipline in the field of management science since the 1950s. After more than half a century of development, risk management research and practice has evolved from insurance-based risk management based on pure risk theory to overall risk management based on the theory of all risk doctrines, and has received government and theoretical circles in countries around the world. And the extensive attention and participation of the business community. In 2004, the Sponsors Committee (COSO) of the National Anti-False Financial Reporting Committee of the United States issued the "Enterprise Risk Management - Integration Framework", officially proposed the concept of "comprehensive risk management" and was widely recognized by the industry. The system transforms the enterprise's comprehensive risk management framework into three dimensions: the target system, the management elements and the main unit, and realizes the whole process embedding of enterprise risk management with the process control thinking. Since then, risk management has entered the era of "comprehensive risk management", and more emphasis has been placed on combining risk control elements such as risk identification, risk assessment and risk aversion with internal control methods such as process design, function setting and information system construction, and has achieved rich research and Practical results.

Specifically, the basic logical architecture of comprehensive risk management has three dimensions: one is the risk management target set, including the organization's strategic goals, business objectives, reporting goals and compliance objectives; the second is the risk management component set, including Internal environment, goal setting, event identification, risk assessment, risk response, control activities, information and communication and control supervision; third, the main body of risk management, including the organization itself, divisions, business units and subsidiaries.

In simple terms, the basic idea of comprehensive risk management can be summarized as: Why, based on what risk management? (Target set setting) - What means is used for risk management? (Feature set setting) - Who is going to risk management? (The subject set is clear). It should be said that the emergence of the concept of comprehensive risk management has largely changed the purely technical genre of "management for management" in the previous research and practice of risk management, and guided the company to be more pragmatic, more goal-oriented, and more emphasis. The full process risk control direction of staff participation and subject responsibility provides an important idea for enterprise risk management, especially financial institution risk management.

\section{Characteristics of Credit Risk Management of Policy-Oriented Export Credit Insurance Institutions}

As the power source and resource center of the modern economic system, the risk management of financial institutions has always been the focus of research in the industry. This aspect is because the risk management ability of financial institutions directly determines the social financing cost and economic development level, and on the other hand, the risk management of financial institutions plays a vital role in the smooth operation of the social and economic system. However, as a very special financial unit, the policy export credit insurance institution has great differences in credit risk management from other financial institutions, mainly in the following three aspects:

\section{(1) Risk Management Objects are Inconsistent}

According to different sources of risk, the Basel Accord divides the risks faced by financial institutions such as banks into three categories: credit risk, operational risk and market risk. The credit risk, that is, the risk of counterparty default, is the main risk faced by financial institutions. The survival and development of the organization has a decisive impact (Gao, 2010). However, for export credit insurance institutions, the concept of credit risk is more special, that is, it not only includes the credit risk of the counterparty (i.e., the insured), but also the repayment risk of the insured's counterparty under the beacon. . In the general business operation process, the focus of credit risk management is often the latter rather than the former.

At the same time, influenced by both policy and extroversion factors, compared with the purely commercialized financial institutions, the external credit risk of policy export credit institutions has greatly increased, in addition to the country's foreign affairs, foreign trade, industry, finance, In addition to factors such as financial factors, international political and economic changes, country risk changes, international industry risk changes, and international financial system risk change factors are all important factors affecting export credit risk. At the same time, as an important source of information for financial institutions' credit review, international credit rating agencies have confirmed in recent years that their rating work is more of a commercial activity (Development Research Center of the State Council, 2013). The rating results have been widely questioned, so it is difficult to make it as a company. The main reference factor for credit decision making. Therefore, the risk management research of policy export credit insurance institutions needs to fully 
estimate the interrelated effects of various risk factors, and establish a new measurement model from the perspective of complex systems for evaluation.

\section{(2) The Nature of the Risk Management Entity is Inconsistent}

Dialectically, policy-oriented export credit insurance institutions can be regarded as a unity of contradictions in three dimensions: First, the contradictory unity of policy and finance, while possessing general financial functions and characteristics such as risk transfer and credit intermediation. Incompletely liberalizing and implementing professional supervision is a powerful financial instrument that reflects the will of the state and safeguards the national interests. Second, the contradiction between market orientation and non-profit is unified. On the one hand, market and customer orientation are the business ideas, and marketoriented The means to open up the market, maintain customers, maintain normal operation by collecting premiums or guarantee consulting fees, and on the other hand insist on not competing with commercial organizations for profit, not for profit, and to play a policy role under the premise of sustainable management. As the most important factor in the evaluation of business performance; the third is the unity of monopolistic and competitive contradictions. Since export credit insurance has strong professionalism and policy orientation, the government generally develops through the establishment or designation of financial institutions. At the same time, some external competitors will be introduced, which will be partially commercialized and have higher risk levels. The business market open door policy of the agency to focus attention and resources on high-risk levels, low levels of development, foreign trade and economic activities have a significant impact on the national economy will be the focus of social support (Wang, 2006). Therefore, for policy export credit insurance institutions, controlling credit risk is not only the need for smooth operation and sustainable development, but also the need to maintain and develop the overall interests of the country.

It is necessary to emphasize that under the idea of "making the market play a decisive role in resource allocation", part of the export credit insurance business originally operated by the policy-oriented export credit insurance institution has gradually introduced commercial organizations to operate concurrently, thereby increasing the market (OECD, 2007). Vitality, better meet the needs of foreign-related business. At the same time, however, the boundaries between policy business and commercial business are still unclear. For those policy businesses that need exclusive monopoly operation, and which are market-oriented businesses that can be fully liberalized, all parties in the market have their own understanding. The understanding is more chaotic. This is completely different from the market full competition hypothesis in traditional risk management research. It is necessary to redefine the boundary and build a credit risk management and control system for policy export credit insurance institutions.

\section{(3) Risk Management Objectives are Inconsistent.}

Knight pointed out that profit is the reward for entrepreneurs to reduce uncertainty. The current risk management research has gradually realized the pure technical level research from "risk management for risk management" to the beginning to understand and study risk management activities from the perspective of value realization of "risk-reward", and regard risk management as " The means of value creation takes the maximization of shareholder value as the ultimate goal of risk management. However, this research perspective is obviously inappropriate when studying the risk management of non-profit organizations, especially policy export credit agencies.

In fact, the sole ultimate shareholder of a policy-oriented export credit agency is the central government. The actual shareholders are mostly central government departments or agency investors designated by the central government. Their mission is to maximize the national interest by maximizing the policy role. Export credit institutions have low requirements for profitability or return on capital, and more require "guaranteed business". Therefore, policy export credit agencies do not have internal vigor to maximize shareholder equity or maximize profits. The research must also start with clear business objectives, and cannot simply apply existing financial institution risk management theories and methods.

\section{Thoughts on Comprehensive Credit Risk Management of Policy-Oriented Export Credit Insurance Institutions}

The formulation and change of a country's foreign economic and trade policies are based on national interests. As an important policy strategy for foreign economic and trade policies, export credit insurance institutions can play a unique role in addition to traditional means such as export tax rebates. Promote the development of foreign trade and economic cooperation. At the same time, for a policy-oriented export credit institution funded by the state, it has no ability and will not provide unconditional and unrestricted full coverage of all foreign trade and economic operations, but should use "good steel on the cutting edge". To maximize the policy role of limited financial resources to better reflect the will of the state and safeguard the overall interests of the country (He \& Wang, 2012). Therefore, for the risk management research of policy export credit insurance institutions, it is necessary to analyze the origin of the policy export credit insurance institutions from the perspective of national interests, and to stand in the complex system. From a scientific perspective, the model of credit risk factors faced by policy-oriented export credit insurance institutions is 
established. On the basis of this, pre-assessment, in-process control, and post-event impairment are the main lines to construct credit risk control of policy-oriented export credit institutions (Yan \& Cheng, 2010). The system can effectively establish a risk management mechanism and contribute to the smooth and sustainable operation of policy-oriented export credit insurance institutions and the promotion of foreign trade and economic development. Specifically, a comprehensive credit risk management system for a well-established export credit insurance institution should include at least the following parts:

\section{(1) The Goal of the Operation of the Credit Risk Management System.}

The operational objectives of the credit risk management system must be based on the overall operational objectives of the organization or organization, and serve the overall goal. The policy export credit insurance institution is no exception. Undoubtedly, the business objective of a policy-oriented export credit institution is not to maximize its own economic interests, but to maximize social benefits, that is, to fully optimize the allocation of credit resources within the scope of capabilities to maximize the overall social benefits of the country or region.

\section{(2) Elements of the Operation of the Credit Risk Management System.}

For export credit insurance institutions, the elements of their credit risk management system should include both the subject and the object ( $\mathrm{Xu}, 2010)$. The main body should be the decision-making unit at all levels, the decision-making and execution department of the risk control policy, and the relevant participants and objects. Refers to the level of credit risk that can be classified, measured, evaluated, and adjusted, including the credit risk of the counterparty (insurant) and the credit risk of the underlying subject (accounts receivable under foreign buyers).

\section{(3) Indicators and Thresholds for the Operation of the Credit Risk Management and Control System.}

In order to achieve effective credit risk control, it is necessary to be able to identify indicator groups that can effectively determine or influence the risk level under the overall framework of credit risk, and set an effective threshold range for each indicator through observation and measurement.

\section{(4) Tools for the Operation of the Credit Risk Management System.}

The credit risk control tools of financial institutions are generally the credit policy and the credit decisionmaking in the specific implementation process (Li \& Wei, 2010). For export credit insurance institutions, the unique control tool is the credit limit under the underwriting policy, that is, the export credit insurance institution for each The maximum liability of the underwriting (overseas buyer) that agrees to assume liability under certain conditions of underwriting.

\section{(5) The Mechanism for the Operation of the Credit Risk Management System.}

That is, how the manager formulates the risk management system operation plan, sets the risk management and control indicators and their thresholds, and through the effective authorization, organization, leadership and control of the participants in the risk management system within the organization, the credits faced in the whole process of the organization operation The process of effective monitoring, early warning and control of risk exposure level is the core of the implementation of credit risk management and control system and the decisive factor of risk management and control effect (Yang \& Luo, 2007).

Therefore, the comprehensive credit risk control of a policy-oriented export credit insurance institution must be based on the mission, objectives and regulations of the organization itself, with the social benefit maximization as the starting point and ultimate goal, and fully evaluate the various stages of the organization's operations and business processes (Xie, 2010). On the basis of the effective identification, measurement and evaluation of risk indicators, setting the thresholds and early warning mechanisms of relevant indicators, and establishing relevant management and control systems can be effectively realized.

\section{The Framework Design of Credit Risk Management for Policy Export Credit Insurance Institutions}

According to the above analysis, under the overall risk management perspective, the design of the credit risk management framework for policy export credit insurance institutions can be based on the company's business objectives and objectives, according to "determined goals", "clear objects", "measure risks", The five dimensions of "determining risk" and "organizational implementation" are carried out.

\section{(1) Determine the Target}

Under the comprehensive risk management framework, the risk management target system includes strategic objectives, business objectives, reporting objectives and compliance objectives. The strategic objectives and business objectives are the cornerstones, the reporting objectives are means, and the compliance objectives are safeguards. The "Provisions" of the policy-oriented export credit insurance institution clearly 
states that the company's business objectives are: "Promoting foreign trade and economic development by providing insurance services for foreign trade and foreign investment cooperation, and focusing on supporting exports of goods, technology and services, especially The export of capital goods such as high-tech and valueadded mechanical and electrical products promotes economic growth, employment and balance of payments. Among them, "promoting economic growth, employment and balance of payments" should be regarded as the company's strategic goal, "promoting foreign economic and trade development, focusing on supporting exports of goods, technology and services" can be regarded as the company's business objectives (Baltensperger \& Herger, 2009).

On this basis, the overall objective of credit risk management of policy export credit insurance institutions can be initially defined as "the risk of the company in each reporting period on the premise of ensuring the maximum export scale of supporting goods, technology and services. Sexual business indicators are limited to certain operating constraints (loss ratio, profit margin, and solvency). The constraints mentioned here include not only the management indicators of the relevant export-oriented credit insurance institutions, but also the short-term management objectives proposed by the policy-oriented export credit insurance institutions. The total constraint curve of the business of the export credit insurance institutions. Under this overall goal, detailed risk management objectives are set according to the three dimensions of insurance, country, and insurance liability maturity.

The credit risk management objective of the policy-oriented export credit insurance institution is to ensure the risk exposure of the policy-oriented export credit insurance institution through real-time monitoring of the exposure value of the underwriting business risk and by adjusting the underwriting policy, increasing or decreasing the size of the liability limit in a timely manner. Levels and expected losses do not exceed regulatory requirements.

\section{(2) Clear Objects}

The "clear object" in credit risk management, that is, credit risk identification, refers to the identification of risk factors by means of perception, judgment and classification, and the setting of specific risk determination indicators to the range of credit risks that may bring losses. Conduct a preliminary determination process $(\mathrm{Ni}, 2014)$.

Different from the general credit risk management, the difficulty of credit risk management of policyoriented export credit insurance institutions lies in the scarcity of financial data of risk-related parties. In addition to the medium and long-term, guarantee business and some large buyers of trade insurance, the finance under other business items Indicators are generally unavailable. Therefore, the traditional Z-value model, the Bathory model and other methods that rely heavily on the analysis of financial indicators cannot be strictly applied to the credit risk management and control practices of policy-oriented export credit insurance institutions. The selection and evaluation of risk indicators must be started from the risk identification stage.

Specifically, the policy-based export credit insurance institution can use the method of "reverse loss" to classify the sources of credit risk in the business into the risk of the insured, the risk of the target and the macro risk. Class, where the insured risk refers to a risk event caused by the insured's default. Due to the product characteristics of policy export credit insurance institutions, policyholders generally do not directly default (refusal to pay premiums), resulting in loss of policy export credit insurance institutions, and more likely due to previous adverse selection (high-risk business selective insurance) or later Failure to cooperate will result in loss of policy export credit insurance institutions.

The underlying risk refers to the risk event caused by the default of the counterparty of the insured transaction. This is the most important feature of the credit risk management of policy export credit insurance institutions, which is different from other financial institutions. It is also the main source of loss for the policy export credit insurance institutions. Based on data availability, such risks can be classified into underlying bankruptcy risk and underlying default risk.

Macro risks refer to risk events caused by macroeconomic and economic factors. Such risks are generally systemic risks and are prone to large-area, systematic loss events. According to the type of risk, it can be divided into five categories: policy change risk, political instability risk, exchange risk, industry risk and other risks.

It should be emphasized that the above risk factors are related to each other and interact with each other. In specific cases, the characteristics of multiple risk factors are often presented at the same time. Therefore, in the stage of risk identification, the policy export credit insurance institution should conduct correlation analysis on historical case data, classify and integrate related detailed risk factors, and ensure that the subsequent risk measurement model can have a high realistic fit. It also provides a scientific reference for subsequent risk control decisions and operations.

\section{(3) Measuring Risk}

Risk measurement, also called risk measurement, refers to the process of quantitatively determining the actual levels of various risk factors through indicator selection and quantitative analysis. Credit risk measurement is the core link of credit risk management. The measurement methods and results directly 
determine the direction and effect of credit risk management. It is necessary to adopt a more scientific calculation method.

At present, the main research methods of credit risk measurement in the world include statistical models, value-based credit risk models, neural networks and support vector machine models. The survival analysis method in statistical models is currently used. A higher rate method that better overcomes the shortcomings of traditional cross-section data. Existing research has proved that survival analysis methods can more effectively predict the probability of corporate bankruptcy than other statistical methods, and can effectively factor industry factors into consideration factors.

Under this method, the policy export credit insurance institution can use the copula function to use the survival analysis method to calculate the overall risk rate of the company's underwriting business categories by integrating the company's historical underwriting, damage, and claims information (death). Probability), and the impact value of each risk factor on the overall risk rate, that is, the quantitative index of the credit risk level of each risk factor, is used to monitor the risk level of the company's business.

\section{(4) Judging Risk}

Judging risk means that the company monitors and manages the real-time early warning system of credit risk by building a credit risk early warning indicator system. Among them, credit risk warning refers to the results based on qualitative and quantitative analysis. Through the judgment of historical risk data and future risk situation, a reasonable threshold (or "threshold") is set, and the dynamic monitoring of the corresponding indicators is completed. Advance feedback on credit risk, laying the foundation for timely risk control. The main difference between risk warning and risk measurement is that risk warning activities must clarify early warning indicators and standards.

At present, the research and practice of credit risk early warning management is basically concentrated in the banking industry. The research on the construction of credit risk early warning system in other fields, especially in the field of export credit insurance, is almost blank. In view of the actual situation of policy export credit insurance institutions, we can consider establishing an initial system of early warning indicators based on the identification and measurement of export credit risks, from the internal and external perspectives. The internal risk early warning indicator system includes the insurer and the insured, respectively considering the insurer's solvency, operating scale growth, financial structure, internal control mechanism perfection and the insured's industry attributes, product attributes, Market attributes and operational stability attributes; external risk early warning system indicators include macroeconomic environment, financial environment, balance of payments, financial institution stability, industry stability, and political and social stability. On this basis, the risk early warning indicators are screened and determined through cluster analysis, and a risk early warning system based on rough set and classifier integration is tried to solve the problem of "how to judge".

This structure has three main functions: one is to strengthen the participation of all members of the credit risk warning and the controllability of the process, and the second is to ensure that the early warning indicators at all levels can complement each other and avoid the post or departmental warning caused by the correlation of risk factors. The existence of blind or missing behaviors to achieve comprehensive management of risk at the company level; third, to be able to effectively communicate with relevant authorities and regulatory authorities on the research results and specific conditions of each level of early warning indicators to improve and enrich external regulatory indicators Form a positive interaction between the company's internal risk control and the external regulatory system.

\section{(5) Organization and Implementation}

On the basis of the above-mentioned risk identification, measurement and early warning, the organization implements the process of establishing a systematic internal control system and constructing a comprehensive credit risk control system. According to COSO's comprehensive risk management framework, the specific implementation departments for implementing credit risk management and control within the enterprise include four levels: enterprise level, division level, business unit, and subsidiary. Considering the actual situation of policy export credit insurance institutions, we can consider adopting a three-level "pyramid" approach to carry out comprehensive credit risk management:

First, the board of directors and management. As the highest decision-making body of the company, this level represents the interests of the country and the company. It is responsible for the formulation and implementation of the company's business line credit risk strategic objectives, business objectives, and policy measures. It designs the company's comprehensive credit risk management system structure and related institutions and personnel., permission settings, and decisions on major risk issues that may exceed companylevel risk warning indicators. As a subsidiary of this level, the company's strategic development department, risk management department and internal control department are responsible for the staff and implementation, and are responsible for the company's overall credit risk level and related early warning threshold settings.

The second is the business management and approval department. This level is the executor of the company's specific business conditions, responsible for the development and monitoring of the company's 
business line credit risk control objectives, the drafting and implementation of business policies, as well as the approval of specific business. Among them, the company's business review committee, as the highest evaluation body, is responsible for the examination and approval of major businesses that may affect the overall credit risk level of each line business and impact on the risk warning threshold. Each management and approval department is responsible for the relevant line business within the authority. Perform sub-rights management.

The third is the business organization. This level includes all the company's direct customer-oriented institutions, including the sales department and branch offices in the field, responsible for monitoring, analyzing and controlling the credit risk level of each business product in the jurisdiction, conducting the approval decision of the business within the authority, and subordinate the business. Unit credit risk control work is guided and managed. The business organization accepts the direct leadership of the company's decision-making level, and at the same time accepts the business line management and guidance of the company's business management and approval departments.

In addition, data collection, model construction, system construction, and process design are a relatively comprehensive and complex system engineering. Information management departments, claims departments and other related organizations all have important positions and play an indispensable role. Through the above structure, it is possible to clarify the positioning and role of all levels and organizations in the comprehensive credit risk management system, and to ensure that the structure of the system is simple and efficient, and to support the overall healthy operation of the company's business.

\section{Conclusion}

Strengthening credit risk management should be one of the important issues in the company's new journey of accelerating development and transformation and achieving a big to strong. This paper summarizes the learning content and research ideas of the company's credit risk management during the study period in Singapore. Based on the review and analysis, the following suggestions are proposed:

\section{(1) Attach Great Importance to Credit Risk Management}

Credit risk is the core business content of financial institutions. Realizing effective credit risk control is not only the lifeline of modern financial institutions, but also one of the core elements for achieving healthy and sustainable development. As a policy-oriented export credit insurance institution, the policy-oriented export credit insurance institution shoulders the national mission, and also accepts external supervision. How to take the "steel wire" of growth and risk control, and realize the development of foreign trade and economic cooperation under the constraints of effective resources. The maximum support should be the starting point and main research ideas of the company's credit risk management work. Therefore, it is recommended that the company pay attention to credit risk management work to increase resource input and build a full-process risk control mechanism.

\section{(2) Fully Understand the Characteristics of Corporate Credit Risk Management}

Policy-oriented export credit insurance institutions as policy-based financial institutions, the objectives of credit risk management are completely different from the concept of "value-first, maximizing commercial interests" of ordinary commercial financial institutions, and the main targets of risk management are also related to other financial institutions. There are significant differences. Therefore, the management of credit risk of policy-oriented export credit insurance institutions should be based on the actual business of the company. Based on the review of the existing credit risk management theory models and practical operation results, it is more suitable for policy export credits. The content of the insurance institution will be abandoned in combination with the actual situation to form the company's own comprehensive credit risk management system.

\section{(3) Firmly Combing the Concept of Comprehensive Credit Risk Management}

Comprehensive risk management is a framework, and it is a concept that can take root. Over the years, in the process of rapid business development, the company has formed a trend of growth of business institutions and control of headquarters departments. The emergence of this situation has the rationality of its division of labor, but at the stage when the current foreign trade tends to be stable and the company's overall business volume has gone out of rapid expansion, especially the global economic climate is insufficient and various international risk factors are high. In the background, it is more necessary for the company as a whole to attach importance to and promote the credit risk management work, especially to give play to the leadership role of the company's decision-making layer in credit risk management and the information superiority position of the business organization in risk management. Can build an efficient credit risk management system covering the whole process of the company's business. 


\section{References}

Baltensperger, E., \& Herger, N. (2009). Exporting against risk? Theory and evidence from public export insurance schemes in OECD countries. Open Economies Review, 2O(4), 545-563.

Development Research Center of the State Council. (2013). Performance evaluation report of China export credit insurance corporation, 2014 edition.

Gao, W. (2010). Free trade and national interests (pp. 5-87). Beijing: China Social Sciences Press.

He, S., \& Wang, S. (2012). Research on China's export credit insurance (pp. 37-98). Beijing: Science Press.

Li, X., \& Wei, Q. (2010). Research on credit risk, export credit insurance and export trade relationship. Journal of Finance and Economics, 25(5), 113-122.

Ni, T. (2014). WTO rules and the maintenance of China's national interests. SAR Economy, 23(6), 6-10.

OECD. (2007). Export credit financing systems in OECD member countries and non-member economies (pp. 8-308). Paris: OECD.

Wang, S. (2006). Export credit theory (pp. 26-183). Beijing: China Finance Press.

Xie, Z. (2010). Analysis of the policy function of export credit insurance- based on the data of Hebei export credit insurance. Insurance Research, 25(11), 104-108.

$\mathrm{Xu}, \mathrm{T}$. (2010). On the economic cycle management of China's credit insurance industry. Insurance Research, 15(4), 56-59.

Yan, Q., \& Cheng, Z. (2010). Official export credit: Theory and practice (pp. 32-61). Beijing: China Financial Press.

Yang, Y., \& Luo, F. (2007). Policy role of export credit insurance in promoting China's export of key industries. Journal of Finance Theory and Practice, 36(1), 25-27. 